\title{
Contact and Colonial Impact in Jamaica: Comparative Material Culture and Diet at Sevilla la Nueva and the Taíno Village of Maima
}

\author{
She Henry and Robyn Woodward
}

For the many indigenous cultures encountered in the Americas by the Renaissance voyages of discovery, and particularly those on the islands of the Caribbean, the arrival of Europeans on their shores led to rapid demographic and cultural decline. Introduction of European diseases, violent confrontations, enslavement, Crown-sanctioned forced labor, and the destruction of traditional cultural patterns resulted from this devastating contact and colonialism. But to simplify these initial encounters into narratives of conquest and devastation is to ignore the profound social change to both the indigenous peoples of the Caribbean and settler European groups that this encounter provoked (Deagan 2004, 597; Patterson 2010, 133). Fifty years of historical and archaeological research has explored both indigenous and European responses to issues of cultural survival and continuity, resistance and power negotiations, accommodation, acculturation, transculturation, and ethnogenesis. This research has demonstrated that depending on the time, geographic setting, and context of these intercultural encounters, there will be significant variations in responses by both the indigenous peoples and European settlers (Deagan 2004, 598). This chapter looks at both the transformation of Iberian material culture, social practices, and diet in households of the elite and non-elite residents of Sevilla la Nueva, the first Spanish capital on the island of Jamaica, as well as the concurrent social adjustment and resistance to the Iberian colonizing efforts that occurred in the adjacent indigenous Taíno village of Maima.

The Spanish colony of Sevilla la Nueva has been explored and analyzed archaeologically on and off through the past century. Excavations reveal a largescale attempt at building the colony into an extensive and productive trading port, capable of supporting further colonization throughout the Caribbean. Excavations conducted at Sevilla la Nueva show the extent of the construction and expectations of this colony, including the building of a town, governor's fort, and abbey. The role and presence of the indigenous so-called 'Taíno' at 
this colony is evident through the presence of a particular style of colonoware known as "New Seville ware" (Woodward 2006a, 2006b). In addition to the material culture excavated from Sevilla la Nueva, historical records indicate that the indigenous peoples were present working under the forced labor system of the encomienda. In 2014 and 2015 (Burley et al. 2017a, 2017b), excavations at the nearby Taíno village of Maima have added to the overall picture of a site impacted by a rich precontact history, protracted contact period, and an ultimately impactful and devastating colonial period.

This chapter will explore the three time periods represented at Maima and Sevilla la Nueva, and the changing and unchanging material culture represented in each. First, the precontact material culture and diet of Maima will be reviewed, creating a baseline from which the later contact and colonial periods effected. Then, the brief contact era, represented by the marooning of Spanish sailors in 1503 within just a few kilometers of Maima. We then explore the colonial era with the founding of the first Spanish capital of Jamaica, Sevilla la Nueva, followed by an exploration and overview of the material culture, specifically colonoware, found at the colonial capital. Finally, we place circumstances seen archaeologically at Maima and Sevilla la Nueva into the broader Caribbean contact and colonial experience. Through the archaeological studies at Sevilla la Nueva and Maima we get a rare glimpse at the effects of both initial contact and colonialism on this indigenous Jamaican village.

\section{History of Indigenous and Proto-Historic Jamaica}

As compared to the eastern part of the Caribbean, where human occupation began around $4000 \mathrm{BC}$, Jamaica was settled comparatively late, less than 1000 years before the arrival of the Spanish. The first settlers on the island were characterized by their Ostionoid ceramics, who expanded across the Jamaica Channel from Hispaniola to the south coast of Jamaica by AD $65^{0}$ (Rouse 1992, 110). The so-called 'Western Taíno' culture gradually replaced the initial Ostionoid culture series in Jamaica and parts of Cuba after AD 880 and was predominant on those islands until the arrival of the Spanish (Rouse 1992, 96). The Late Ceramic Age indigenous peoples of Jamaica had a distinctly different material culture from that of their predecessors, which is characterized by their own ceramic tradition, White Marl style, that fits within the regional Meillacoid series (Meillacan Ostionoid sub-series) (AD 950-1500). Despite their isolation, and different ceramic styles, these so-called 'Western Taíno' of Jamaica shared some linguistic and cultural traits with the Classic Taíno peoples of Hispaniola and Puerto Rico (Atkinson 2003, 1); thus it might be assumed that as 
on Hispaniola, ceramic production, basket and mat making, and weaving and spinning of cotton was done by the women in the community (Deagan 2004, 601). Defining the indigenous peoples of the Caribbean under one name however has come under scrutiny of late (Curet 2014; Keegan and Hofman 2017) with scholars leaning more towards an individual look at differing cultures around the Caribbean rather than one defining 'Taíno' identity.

Despite not defining the indigenous Caribbean peoples under one title, they do share certain cultural traits. They have similar stone tool traditions and agricultural practices, such as the mounding of fields into conucos, for the cultivation of cassava. In addition to cassava, they introduced and cultivated sweet potatoes, beans, peppers, squash and peanuts (Rouse 1992). Once the conucos were built, the only labor required was periodic planting and harvesting which appeared to have been done by all members of the community (Lee 1980, 2; Rouse 1992, 170). Guava, mamey, pineapple and tobacco were all additional Taíno cultigens, and cotton was cultivated and traded between the islands (Deagan 2004). Of these domesticates, only cotton and tobacco were exploited by the Europeans on a widespread commercial basis over the five centuries (Rouse 1992, 12). To supplement their protein intake the indigenous inhabitants harvested a diverse array of both inshore and deep-water species of fish and shellfish and trapped hutias, a member of the rodent family, which was the only terrestrial mammal indigenous to the island (Faerron 1985, 2; Wing 2001).

Social organization among the Western Taíno of Jamaica centered around polities of allied villages with perhaps eight to ten principal chiefs, or caciques, although Wesler suggests that structures may have included simple and complex chiefdoms at the time of contact (Wesler 2013, 253; Wilson 2007, 110). Little is written about the Taíno mythology that was practiced on the island or if both men and women participated in community rituals as was the case on Hispaniola. The Taíno population of Jamaica in 1494 was estimated to be at least 6o,0oo although some anthropologists believe the island had a population base of at least 100,000 (Wilson 2007).

Spanish engagement with the Taíno of Jamaica began on May 5, 1494 when Columbus sailed into the bay of Santa Gloria (later St. Ann's Bay) while on his second voyage to the Americas. Columbus gave the Taíno assurances of good faith and peace and passed out trade trinkets as a gesture of goodwill. Over the succeeding days, with but one instance, they traded small trinkets for gifts of food as they sailed west along the north coast of the island (Padrón 2003, 3). Over the course of the next decade there are no reports of other Spaniards visiting the island, save for Alonso de Hojeda's provisioning run along the south 
coast of the island in 1502, most probably because Columbus had noted in his report to the Crown in 1494 that there was no gold on the island (Morison 1942, 643; Wright 1921, 71).

In June 1503 on the final and fateful leg of his fourth voyage of exploration Columbus was forced to seek shelter in Santa Gloria as the two remaining ships of his squadron were too waterlogged to make it back to Santo Domingo on Hispaniola. For more than a year Columbus and his men endured, at times, uneasy relations with the local Taíno, with whom they traded for food (Morison 1963; Padrón 2003, 8). Columbus himself was silent about this time in his journals, however, his eldest son Diego Colón who accompanied him on the voyage kept an historic account of the year's events. During this time, he noted in his journal that the island was thickly populated and the Taíno village of Maima was about a league distance from his beachhead and named Aguacadiba as the village with whom they traded for hawk bells, small glass beads and lace tips for cassava, maize, hutia and fish (Morison 1942, 643; 1963, 356). Despite being forced into dependent transactions for their very survival, Columbus made only sparse ethnographic observations about the communities that surrounded their beached ships (Morison 1963, 367; Wesler 2013, 253).

In 1508, Diego Colón was appointed Governor of the Indies. In an effort to forestall any further erosion of his family's claims in the New World, he ordered a former military officer Juan de Esquivel, to take 6o settlers and establish a settlement, in the bay of Santa Gloria, which was known to have both a sheltered harbor and a large, peaceful indigenous populace (Padrón 2003, 51-52). Esquivel was charged with establishing agricultural and ranching properties with an aim at producing supplies for local markets and colonizing efforts in Central America (Wright 1921, 71). As a native of Sevilla, Esquivel named his settlement, Sevilla la Nueva (Padrón 2003, 52).

Initially Esquivel enjoyed the confidence of the Crown and he reportedly showed enthusiasm for the conversion of the indigenous peoples and had distributed land and indigenous laborers to some of his men through the feudal institution of encomienda (Rouse 1992, 19). The encomenderos, the Spanish who received these entitlements, could extract tribute from their indigenous workers in the form of food, precious metals, or direct labor services in exchange for protection and instruction in the Catholic religion and civilization (Woodward 2006a, 63; Yaeger 1989, 843). In his reports to the king, Colón indicates that Esquivel had promoted agricultural endeavors and introduced cattle, sheep and sugar cane to the island (Padrón 2003, 54). However, in another report made by Pedro de Mazuelo, the settlement treasurer remarked that given their 
brutal treatment, the settlers would likely run out of indigenous labor in two years (Padrón 2003, 149). As a result of this cruel behavior, the local indigenous groups rose up against the Spanish and the encomienda system. In response, Esquivel rounded up the local caciques, killing them in a show of power and control, after which there were no further rebellions.

Resulting from the inhumane treatment of the indigenous peoples and the reports the Crown was receiving about the labor shortfalls, in 1513 the King ordered a residencia (routine review of an official's tenure) of Esquivel's governorship. This report faulted him for his management of the indigenous population that had occurred two years into his administration, and claimed he had initiated a system of favoritism with respect to land and labor grants (Padrón 2003, 53-54). He was dismissed and in 1514 they conferred the position of Governor of Jamaica on Francisco de Garay a successful gold miner, ship owner, slave trader, entrepreneur, and administrator on Hispaniola between 1594-1513 (Padrón 2003, 53). In late 1514, prior to returning to the Caribbean, Garay met with King Ferdinand and entered into a five-year asiento partnership agreement with his Royal patron with regards to the economic development of the island (Floyd 1973, 137; Weddle 1985, 97).

On his arrival Garay undertook an accurate census of the island's indigenous population to determine the number of indigenous laborers available for distribution to the colonists. Although this report has not survived, it is understood that in his capacity as repartidor, he redistributed a number of indigenous laborers to numerous officials and new settlers, as well as, assigning men to the new royal estancias (farms), in which he was a partner (Padrón 2003, 150; Wright 1921, 73). Jamaica was very prosperous under Garay's administration, the Spanish population continued to expand, and he established two more towns on the island, Oristán on the south coast, and Melilla, 12 to 14 leagues east of Sevilla la Nueva, neither of which has been found. He built the first sugar mill on the island and was in the process of building a second when he left the island in 1523 to pursue his claim on a portion of Mexico. His departure drained the island of manpower and the ships needed to transport its products to regional markets.

In the absence of Garay's capital and able administration the fate of Sevilla la Nueva was in the hands of the island's treasurer, Pedro de Mazuelo, who proceeded to manipulate the affairs of the island to benefit his plantation on the south side of the island. During the 25 years that Sevilla la Nueva was occupied, archival sources document the employment of indigenous labor in the fields, tending animals on the estancias as well as building the church (Padrón 2003; Woodward 2006a; Wright 1921; Wynter 1984). 
Even though Sevilla la Nueva was only established for 25 years, archaeological investigations over the past 70 years of this site have demonstrated that the early sixteenth-century Spanish colonial remains are both diverse and well preserved, albeit deeply buried under thick layers of alluvium (Cotter 1948, 1970, n.d.; Hammond 1970; Lakey et al. 1983; López y Sebastián 1982, 1986a, 1986b, 1987; Osborne 1973; Woodward 1988, 2006a, 2006b). Both Cotter and Osborne assumed they were dealing with single event deposits, so they employed basic horizontal controls during their excavations, and Cotter kept adequate notes over the course of the eighteen years he worked on the site. The Spanish Archaeological Mission under the direction of Sr. López y Sebastián worked on the site for eight years, excavating some $3272 \mathrm{~m}^{2}$ or $4 \mathrm{~m}^{2}$ units but other than three short preliminary reports that identified the site, they did not publish their research on the artifacts or file copies of their notes/maps with the Jamaica National Heritage Trust. The archaeological program initiated by Woodward and a team from Simon Fraser University and the Jamaican National Trust included topographical mapping, electromagnetic conductivity survey and testing, auger coring and areal excavations. The research design and sampling techniques for all the post-2001 excavation units at Sevilla la Nueva and Maima included strict horizontal controls and arbitrary vertical controls fine screening of all the deposits leading to a more robust data base from which it has been possible to draw more nuanced interpretations.

Far from being the "black hole" of precontact archaeology of the Caribbean and circum-Caribbean, Jamaica actually has a rich database of surveys and excavations from all regions of the island, although until the last few decades much of this has been conducted and published locally rather than disseminated to a wider audience. Carbon-14 dates obtained from a number of indigenous sites in Jamaica suggest that they were occupied well into the Spanish period (Wesler 2013, 255, 259). Data from other documented contact period indigenous sites suggest that European objects (fragments of glass, ceramic metal) were only minimally present. Sampling designs of many of the early projects on Jamaica did not go beyond rough sorting or ceramic and faunal remains, making recovery of all the European plant and animals remains unlikely. The absence of European materials on these sites however has helped to reinforce the assumption that the Taíno either abandoned their villages shortly after contact or did not survive long enough to generate detectable archaeological deposits (Deagan 2004, 603). 
A number of indigenous sites were noted on the hills surrounding St. Ann's Bay, including a large site, a "quarter league" southwest of the Spanish Governor's fortress that has been identified as Maima (Burley et al. 2017a; Burley et al. 2017b). Some work was done on the eastern edge of this site by Spanish archaeologists in the early 1980 s that was not reported on and the material covered in the project were not fully studied (López y Sebastián 1986a). As indigenous involvement at Sevilla la Nueva was clearly demonstrated by the pressence of later period White Marl pottery and a type of colonoware (Woodward 2006a 2006b), the potential to correlate archaeological features from both the Spanish and adjacent indigenous site with the extraordinarily rich reserve of archival documentation prompted a re-examination of materials to gain a better understanding of how the Spanish adapted to their new surroundings and how the indigenous peoples responded to both Spanish usurpation of their traditional lands and the imposition of the encomienda.

Over the past 40 years the organization of archaeological materials into functional categories for the purposes of quantitative analysis has enabled archaeologists to both organize and compare materials from analytical units of like functions such as households, workshops, churches etc. to address questions about labor, exchange, diet, and gender (South 1977, Deagan 2004, 611). For the purpose of this chapter only household units with their emphasis on living quarters and workspaces were considered for comparative analysis. From the Spanish town site, then the elite residence of the governor's fort, excavated by Cotter in the 1950s and the remains of a non-elite residence (Spanish House Area 6) that was identified in 2009, adjacent to the Spanish meat processing feature (Industrial Area) were included in this study (Figure 4.1).

During excavations carried out in 2014 and 2015 at Maima, now a part of the Seville Heritage Park, a team of archaeologists from Simon Fraser University identified the indigenous village as the Maima noted in the Columbus chronicles (Burley et al. 2017a). Five house units were excavated in 2015 with three (houses 7,8 , and 10) producing significant artifacts and material culture representative of the late precontact period, and two (houses 7 and 10) including artifacts from the contact era. House 10 in particular includes indications of being an elite household as well as including a large portion of contact era artifacts. Elite artifacts from the precontact era include a number of ceramic faces, and the highest percentage of decorated ceramic fragments. While these indications may point to an elite household, further research and data would be needed to explore the nature and extent to which House 10 held social or economic status within the community.

Precontact data shows that the indigenous villagers at Maima produced ceramics similar to those found at other late precontact Jamaica sites across 


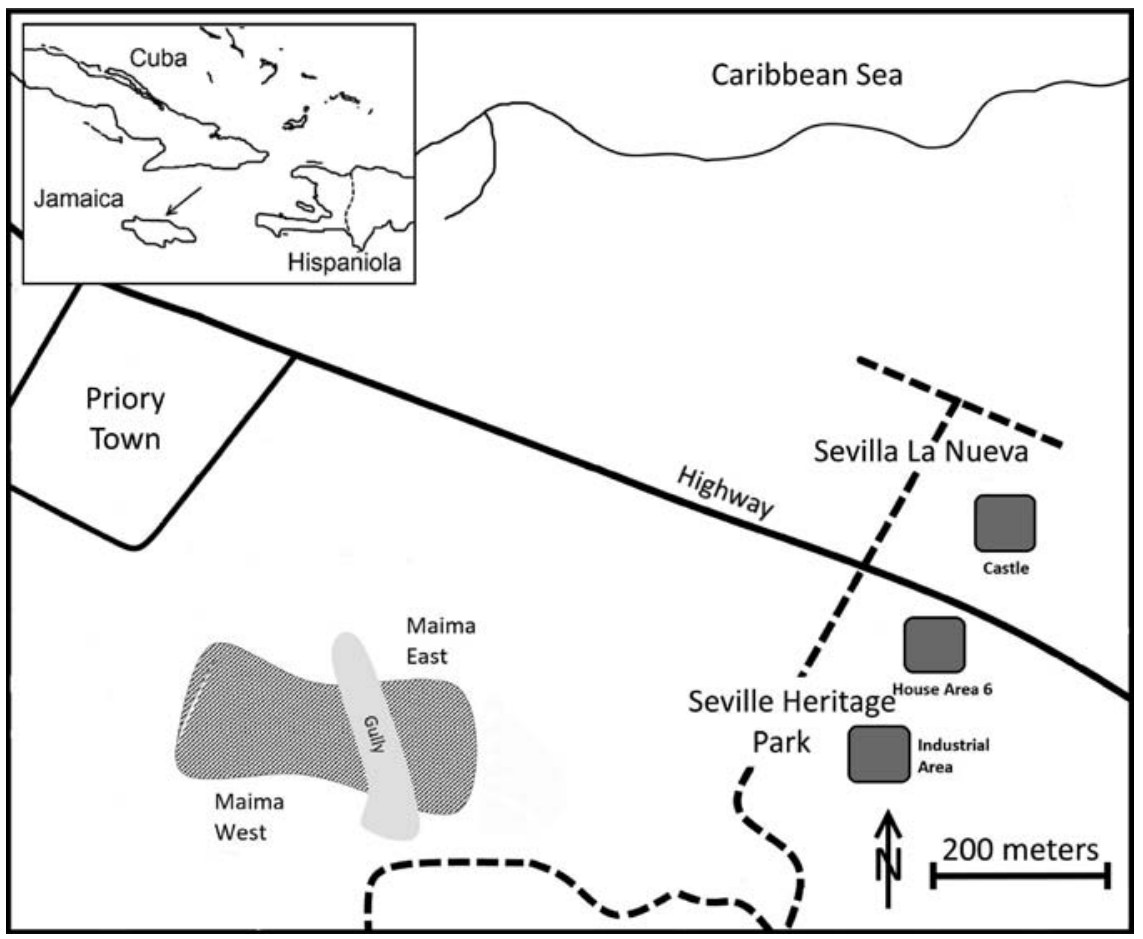

FIGURE 4.1 Map of Sevilla la Nueva and Maima, Jamaica, with areas excavated, modified from Burley et al. 2017a

Jamaica and the surrounding region (Figure 4.2). The characteristic filleted rims, vessel forms, geometric designs, and surface decoration are all present at Maima (Burley et al. 2017b, 38-39). Faunal remains were found in small amounts, but those recovered from midden contexts throughout the site indicate that fish and shellfish were the primary source of protein, coming mostly from the shallow reef within a kilometer of the village (Henry 2017). Hutia, a medium sized rodent, were also eaten but represent only $15 \%$ of the total faunal bone assemblage. Age profiles of the hutia at Maima indicate that they were likely kept in some form of domestication as primarily young immature hutia are represented, consistent with herd management behavior (Wing 2001, 2008). Historical accounts from Diego Colón note the Taíno bringing the Spanish hutia upon their arrival, suggesting that they were easily accessible yet prized enough to offer the newcomers (Morison 1963). The Spanish sailors likened the rodent to rabbit but claimed that it did not satisfy their strong desire for meat (Morison 1963, 356).

The artifacts excavated at Maima also show a general continuity between the precontact, contact, and colonial eras. Fish and shellfish data indicate that 


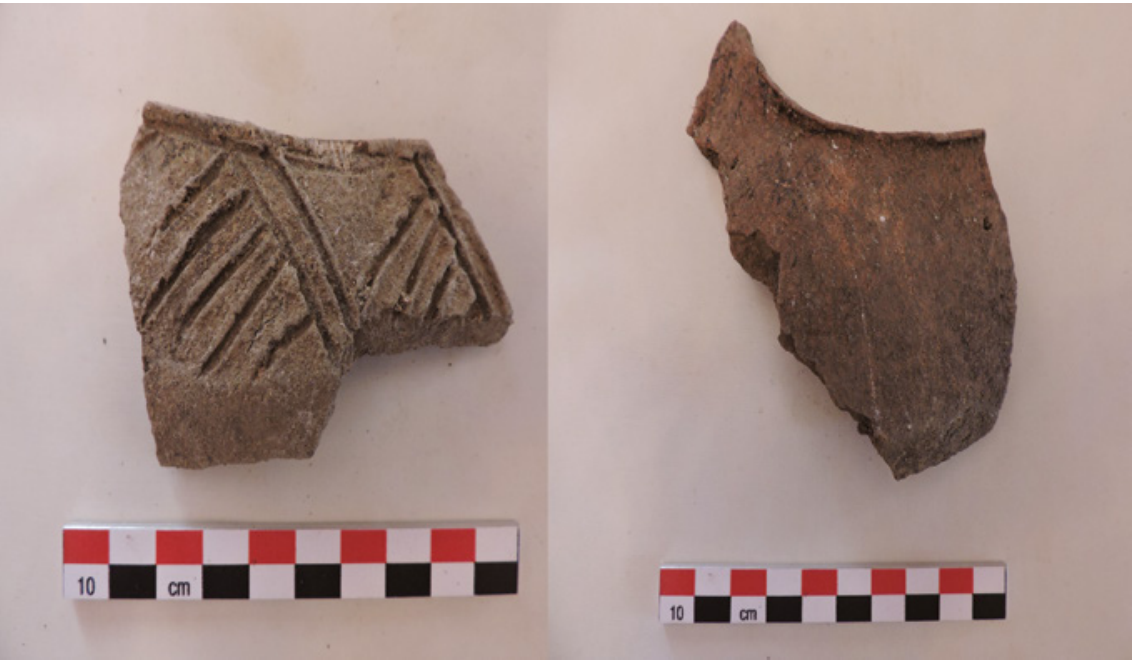

FIGURE 4.2 Examples of traditional Taíno pottery recovered from excavations at Maima, Jamaica

the villagers collected most of their meat products from the nearby reef, with $89 \%$ of the total fauna coming from a shallow marine environment (Henry 2017). As Maima is approximately $1 \mathrm{~km}$ from a reef located in what is now St Ann's Bay it is likely that it was there that the Taíno fished. The percentages of fish and shellfish taken from reef environments does not change over time nor does it change within the levels associated with contact era artifacts. The diet remains the same throughout the rest of the site until the abandonment of the village. Other artifact types, including ceramics and lithics also maintain continuity through the entire occupancy of the site.

The contact era artifacts are the most representative of the European material culture at Maima. After Columbus and his crew landed in what is now St. Ann's Bay, historic records from Diego Colón and Diego Mendez state that the marooned Spanish traded items from their ship in exchange for food, information, canoes, and other supplies (Morison 1963, 356). At Maima in particular, European items were traded primarily for food. European artifacts found at Maima fit with these historic accounts with the uncovering of Spanish nails, three glass fragments, and two pieces of unidentified metal (Burley et al. $2017 \mathrm{~b}$ ). It is possible that these artifacts were deposited at Maima during the initial contact in 1503, or during the later colonization in 1509, however these are all objects that the Spanish would have had in that initial contact.

Artifacts that can be placed solidly into the colonial era at Maima are the few fragments of European domestic animals, imported by the Spanish for Sevilla la Nueva. These faunal remains include two sheep/goat metatarsals and a single cow tooth. The marooned Spanish that arrived at the initial contact did 
not carry these domesticates with them and therefore must represent a later time period. There are no cut or butcher marks on either of these bones and it is possible that they do not represent food remains, rather were taken as oddities during the colonial era.

\section{Colonoware and Transculturated Material Culture}

The site of Sevilla la Nueva contains the multiple habitation and work areas that were constructed for the colony. The excavations conducted over the past 70 years include the sugar mill, artisan's quarters, governor's fort, abbey, households, and wells. These excavations produced thousands of artifacts representing material from industrial, utilitarian, elite, non-elite, household circumstances among many others. This chapter draws data specifically from three areas of the site, the governor's fort, Spanish house area 6 and the industrial area. At each of these locations indigenous or Meillacoid ceramics, colonoware, and Spanish ceramics, in differing percentages were found. Each area had the potential to have indigenous laborers and Spanish colonists present.

TABLE 4.1 Spanish and Taíno pottery recovered from three excavation areas at Sevilla la Nueva, Jamaica

\begin{tabular}{|c|c|c|c|c|c|c|}
\hline Description & $\begin{array}{l}\text { Governor's } \\
\text { Fort }\end{array}$ & $\%$ & $\begin{array}{l}\text { Spanish } \\
\text { Area } 6 \\
\text { House }\end{array}$ & $\%$ & $\begin{array}{l}\text { Industrial } \\
\text { Area }\end{array}$ & $\%$ \\
\hline $\begin{array}{l}\text { Spanish } \\
\text { Majolicas }\end{array}$ & 191 & 6.83 & 55 & 8.99 & $5^{0}$ & $1.5^{8}$ \\
\hline $\begin{array}{l}\text { Misc. Glazed } \\
\text { Spanish Wares }\end{array}$ & 76 & 2.72 & 145 & $23 \cdot 7$ & 123 & $3 \cdot 9$ \\
\hline $\begin{array}{l}\text { Unglazed Span- } \\
\text { ish Earthenwares }\end{array}$ & 101 & 3.61 & 15 & 2.41 & 49 & 1.5 \\
\hline Olive Jar & 591 & 21.18 & 31 & 5.1 & 69 & 2.28 \\
\hline Sugar Moulds & & & & & 2426 & 76.8 \\
\hline Roof Tiles & & & 79 & 12.9 & 44 & 1.39 \\
\hline Taíno Ceramics & 1781 & $63 \cdot 77$ & 287 & 46.9 & 369 & 11.69 \\
\hline Manioc Griddle & 16 & 0.57 & & & 21 & 0.66 \\
\hline New Seville Ware & 37 & 1.32 & & & 6 & 0.2 \\
\hline Total & 2793 & 100 & 612 & 100 & 3157 & 100 \\
\hline
\end{tabular}


Beyond ceramic artifacts, the majority of the material culture represented at the site is Spanish.

In addition to the Spanish material culture, Meillacoid ceramics have been identified in nearly every location around the site. Through an analysis of the rim and decorated sherds in the Sevilla la Nueva collection, there is no evidence that ceramic styles underwent any kind of change during the colonial era (Woodward 2006b). The filleted rims and decoration styles noted on the ceramic fragments found at Sevilla la Nueva match entirely with those excavated at Maima in the more recent excavations. These unaltered and unchanged Meillacoid ceramics at Maima indicate first that there was contact and connection between Maima and Sevilla la Nueva as these ceramics likely passed between the forced laborers going back and forth to their home, and second the continued use of traditional styles rather than completely integrating Spanish material culture.

The colonoware, known from this site as New Seville ware (Woodward 2006a, 2006b), is represented by the use of traditional indigenous ceramic materials and methods, manufactured into Spanish styles. New Seville ware is characterized by the sandy, pale brown to yellowish-brown paste. They are constructed through hand-formed coils, as opposed to the wheel thrown European ceramics. Thirty-six sherds and seven vessels can be identified as New Seville ware, representing domestic ceramics including bowls and cups (Figure 4.3). The appropriation of local materials and ceramic manufacturing

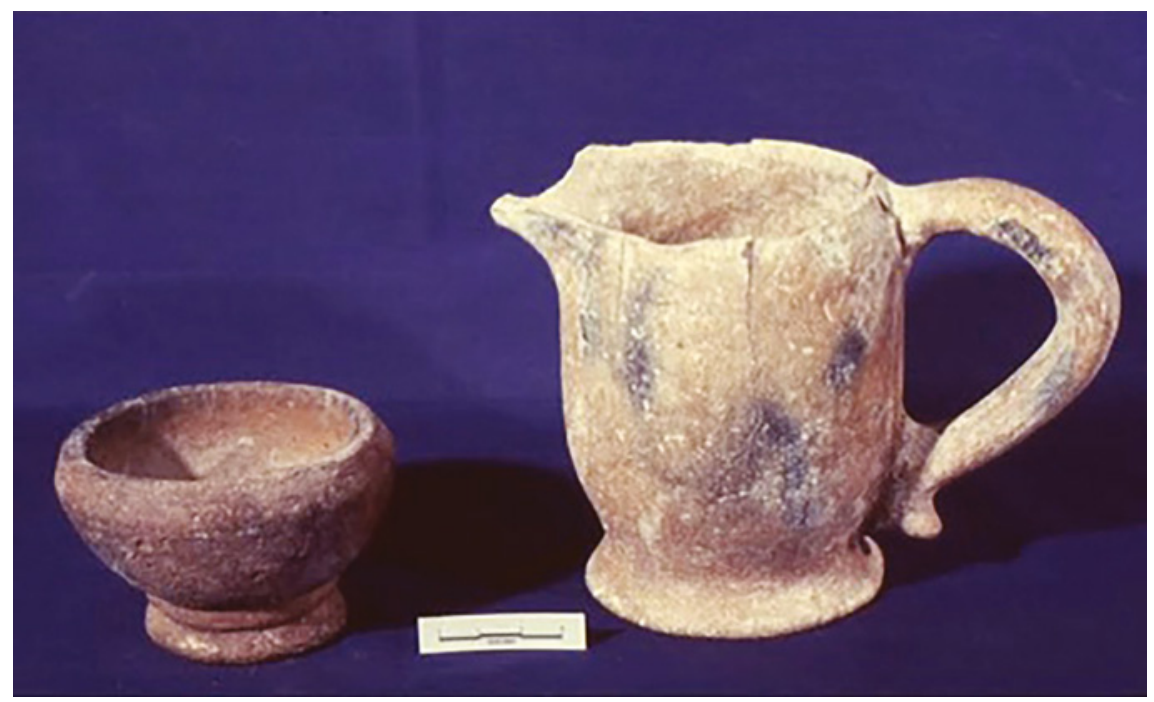

FIGURE 4.3 New Seville ware recovered from Governors Fort at Sevilla la Nueva, Jamaica 
techniques is directly representative of the encomienda forced labor system in place at Sevilla la Nueva. Local potters were being used as craft producers as part of their service to the colony. The two examples pictured in figure 4.3, the jug and pedestal cup, were both found at the governor's fort, and were likely used as tableware for the governor (Woodward 2006b, 171). Two vessels found at the governor's fort are incised with traditional Meillacoid decorations similar to those found at Maima (Figure 4.3). These decorations act as a stamp put on these wares from the indigenous potters forced to make them.

The majority of colonoware at Sevilla la Nueva was found at the governor's fort, however, the Meillacoid ceramics are much more represented throughout the site. We can trace the presence of the indigenous peoples across the site by where and how much of Meillacoid traditional ceramics and colonoware is found. The most are found at the castle, where the indigenous peoples would be laboring to build the ornate and complex governors fort, which acted as his residence. A large number of Meillacoid ceramics were also found in the industrial area, also likely from the indigenous laboring at the sugar mill and in the artisan's quarters where the bricks and decorations were made for the castle and abbey. The Meillacoid ceramics found at the house site are possibly representative of the indigenous women that were taken as wives by the Spanish (Woodward 1988). According to Spanish records, single male colonists were encouraged to marry indigenous women in order to grow the population of the colony and ensuring its progress and success (Padrón 2003, 58). However, no colonoware was found in domestic areas but only in the governor's fort, and industrial area. In that way it seems to suggest that the colonoware was created for the Spanish and not for use by the indigenous peoples. In particular, it was used most in the elite area of the colony by the governor specifically.

At Maima, only a few small fragments of Spanish roof tile and no pieces of colonoware matching that of Sevilla la Nueva were found. The roof tile was located in house unit 10 along with two glass fragments, three European domestic animal faunal fragments, and nine nails. While we know from historic records, and these fragmentary pieces of European goods found at Maima, that it was occupied concurrently with Sevilla la Nueva, the Maima villagers did not significantly incorporate either European material culture or colonoware, into their daily lives. Since the majority of contact and colonial era artifacts found at Maima were recovered from house unit 10, which is possibly representative of an elite household, it is possible that the unique Spanish artifacts were being held by the elite, a pattern noted in other sites in the Caribbean (Ernst and Hofman this volume; Hofman et al. 2014; Keehnen this volume; Samson 2010; Valcárcel Rojas this volume; Valcárcel Rojas et al. 2013). 
The idea that the indigenous peoples of the Caribbean were devastated immediately and without reaction, the "fatal impact" model, was a commonly held misconception for decades within archaeological and particularly historical research (Silliman 2005). Despite this, more recent researchers have been finding that the indigenous Caribbean islanders utilized a number of behaviors and adaptations to counter this destructive and impactful colonialism. The study of contact and colonial era, from the perspective of the indigenous islanders, is a dynamic and changing field, with various patterns and models being observed. As this volume displays, the response to contact and colonialism is dynamic and never the same in one place. This is particularly true in their study of concurrent and nearby indigenous settlements in Cuba in which one area resisted the inclusion of Spanish material culture, while another did not (Valcárcel Rojas et al. 2013). Other scholars and research done in the Caribbean note the incorporation of Spanish artifacts into the daily lives and cosmologies of the indigenous peoples (Deagan 1988, 1996; Keehnen 2010). Deagan (2004) in her study of the indigenous village of En Bas Saline in present-day Haiti, introduces a colonial model in which the indigenous peoples were taken from their villages for part of the year, made to work for the Spanish, then were able to return to their villages for the remainder of the year. She notes that despite sharing their time between their home communities and the Spanish settlements, there was little European material culture found at the indigenous village. This pattern is observable at other indigenous Caribbean sites (Deagan 2011; Hauser and Armstrong 2012).

The continuity observed in the archaeology at Sevilla la Nueva and Maima between the precontact, contact, and colonial eras provides evidence less of transculturation but of forced labor and resistance between these colliding and vastly different cultures. The Maima village, by all archaeological accounts, represents a settlement similar to those surrounding it from the time. They made pottery similar in style and design to other White Marl Jamaican sites. They grew crops we expect to see at indigenous villages, raised and/or hunted hutia, and gathered fish and shellfish from the local reef. This way of life and subsistence strategy maintained itself through the contact and colonial eras.

Contact at Maima, though short lived at most sites and hard to locate archaeologically (Deagan 2004; Valcárcel Rojas et al. 2013), was sustained for a full year, while the marooned Spanish sailors relied on the indigenous peoples for subsistence. Despite a sustained contact, a single year is as unlikely to be represented in the archaeological record as a single moment of contact. However, the small number of Spanish nails and glass fragments found at Maima point to this initial, though difficult year for both the Spanish and the indigenous 
peoples. If not for the founding of Sevilla la Nueva, life may have gone back to normal at Maima, but only five years later the Spanish returned to the area to found their island capital, with the reasoning that there were close sources of indigenous labor (Woodward 2006a).

Colonialism had the most devastating and untimely destructive impact on Maima. With the enforcing of the encomienda, villagers were removed from their home and made to live and work at Sevilla la Nueva. Ceramic evidence from the settlement show that the indigenous peoples were not only working at the colony, but also living there based on the household items found including cassava griddles, metates, and Meillacoid-style pottery. As Sevilla la Nueva was an agricultural and resupply stop and did not involve mining or resource extraction, the encomienda likely involved agricultural and household labor. It is unclear from the historical records whether men were taken away from the island and sent to mine precious metals on other islands or whether they were made to work in the fields. It is also unclear whether women were forced into labor through the encomienda system or through marriage to the Spanish settlers, which was encouraged by Crown and colonial leadership to increase the settlement population (Padrón 2003, 150; Woodward 2006a).

The women that were made wives and/or domestic laborers to the Spanish were likely the manufacturers of the colonoware observed at Sevilla la Nueva, leaving their mark on the Spanish material culture, similar to that seen at Puerto Real (Deagan 2004). Whether they were able to return to their village of Maima, or whether other indigenous peoples working under the encomienda returned, they did not return with Spanish items. They were also likely not using the colonoware made at Sevilla la Nueva as most of it was found at the elite Spanish residence by the governor and not by the indigenous peoples making it.

This rejection of Spanish material culture at Maima is adding to a growing body of literature suggesting that the indigenous peoples resisted Spanish influence in their lives outside of the Spanish settlements. While indigenous influences on Spanish material culture can be seen through the creation of colonoware at Sevilla la Nueva, a passive resistance to the colonialism that was quickly devastating their population was occurring at Maima. Ultimately, and likely quickly, Maima was abandoned, leaving behind few traces of the devastating European contact that forever altered their lives and culture.

This type of passive resistance, the non-incorporating of European culture into the indigenous goods, whether modified or unmodified can be seen at contact and colonial sites throughout the region (Deagan 2004, 2011; Hauser and Armstrong 2012). It is unclear whether the Maima villagers were intentionally not incorporating European material culture and design into their village life or whether they did not have the opportunity, having been taken away from their homes and made to live at Sevilla la Nueva. However, putting 
intentionality aside as Deagan (2011) suggests, the end result is the same, the material culture of Maima remained unchanged until the abandonment of the village. The abandonment itself being a further act of resistance, escaping not only the encomienda but the Spanish cultural influence and devastation.

Evidence at Maima of the precontact, contact, and colonial eras make it a unique and important site for the study of the impact of colonialism in Jamaica and the Caribbean. The villagers of Maima were impacted by a long protracted contact as well as a quickly devastating colonial period that lead to the ultimate abandonment of their village. In that short time however, the villagers showed a resistance to the culture and influence of those colonizing them. By being subjected to a strained transculturation at the Spanish settlement through a forced labor system, but not bringing that culture back to the indigenous village shows a purposeful rejection of Spanish material culture and style. This response to contact and colonialism adds to the ongoing research being done on the differing and dynamic reactions by the indigenous peoples of the Caribbean to the devastating impact of colonization.

\section{References}

Atkinson, Lesley-Gail. 2003. "Jamaican Redware Revisited." Presented at Archaeological Society of Jamaica Symposium: Zemis, Yabbas and Pewter: The Diversity of Jamaican Archaeology, Kingston, Jamaica, 3 April.

Burley, David V., Robyn P. Woodward, Shea Henry, and Ivor C. Connolley. 2017a. "Jamaican Taino Settlement Configuration at the Time of Christopher Columbus." Latin American Antiquity 28 (3): 337-352.

Burley, David V., Robyn P. Woodward, Shea Henry, and Ivor C. Connolley. 2017b. Report on the Survey and Excavations at Maima, A Late Prehistoric/Proto-Historic Taino Village in St. Ann's Bay, Jamaica. Report Submitted to Jamaican National Heritage Trust, Kingston.

Curet, Antonio L. 2014. “The Taino: Phenomena, Concepts, and Terms." Ethnohistory 61 (3): 467-495.

Cotter, Charles S. 1948. "The Discovery of Spanish Carvings at Seville." Jamaica Historical Review 1 (3): 227-233.

Cotter, Charles S. 1970. "Sevilla Nueva: The Story of an Excavation." Jamaica Journal 4: $15^{-22 .}$

Cotter, Charles S. N.d. "Field notes of excavations at Sevilla la Nueva."

Deagan, Kathleen A. 1988. "The Archaeology of the Spanish Contact Period in the Caribbean." Journal of World Prehistory 2 (2): 187-233. 
Deagan, Kathleen A. 1996. "Colonial Transformation: Euro-American Cultural Genesis in the Early Spanish-American Colonies." Journal of Anthropological Research $5^{2}$ (2): 135-16o.

Deagan, Kathleen A. 2004. "Reconsidering Taíno Social Dynamics after Spanish Conquest: Gender and Class in Culture Contact Studies." American Antiquity 69 (4): $597-626$.

Deagan, Kathleen A. 2011. "Native American Resistance to Spanish Presence in Hispaniola and La Florida, ca. 1492-1650." In Enduring Conquests: Rethinking the Archaeology of Resistance to Spanish Colonialism in the Americas, edited by Matthew Liebmann and Melissa S. Murphy, 41-56. Santa Fe: School for Advanced Research Press.

Faerron, Judith C. 1985. “The Taínos of Hispaniola." Archaeology Jamaica 85 (1): 1-4.

Floyd, Troy S. 1973. Columbus Dynasty in the Caribbean, 1492-1526. Albuquerque: University of New Mexico Press.

Hammond, Phillip C. 1970. "Stratigraphic and Electronic Survey: 1970 Season. Seville (Sevilla la Nueva), St. Ann's Bay, Jamaica." W.I. Kingston, Jamaica, on file at the Jamaica National Heritage Trust Commission: 93.

Hauser, Mark W. and Douglas V. Armstrong. 2012. "The Archaeology of Not Being Goverened: A Counterpoint to a History of Settlement of Two Colonies in the Eastern Caribbean." The Journal of Social Archaeology 12 (3): 310-333.

Henry, Shea. 2017. "Late Pre-Contact Era Taino Subsistence Economy and Diet: Zooarchaeological Perspectives from Maima." PhD diss., Simon Fraser University.

Hofman, Corinne L., Angus A.A. Mol, Menno L.P. Hoogland, and Roberto Valcárcel Rojas. 2014. "Stage of Encounters: Migration, Mobility and Interaction in the PreColonial and Early Colonial Caribbean." World Archaeology 46 (4): 590-6o9.

Keegan, William F. and Corinne L. Hofman. 2017. The Caribbean Before Columbus. Oxford: Oxford University Press.

Keehnen, Floris W.M. 2010. "Conflicting Cosmologies: The Exchange of Brilliant Objects between the Taíno of Hispaniola and the Spanish." in Communities in Contact: Essays in Archaeology, Ethnohistory, and Ethnography of the Amerindian CircumCaribbean, edited by Corinne L. Hofman and Anne van Duijvenbode, 253-268. Leiden: Sidestone Press.

Lakey, Denise, Bruce F. Thompson, Thomas J. Oertling, and Robyn P. Woodward. 1983. The 1981 Survey of Sevilla la Nueva. College Station: Department of Anthropology, Texas A\&M University.

Lee, James W. 1980. “Arawak Burens." Jamaica - Archaeology 80: 1-11.

López y Sebastián, Lorenzo E. 1982. "Sevilla la Nueva (Jamaica): Un Proyecto de Arqueología Colonial." Revista Espanola de Antropología Americana XII: 292-300.

López y Sebastián, Lorenzo E. 1986a. "Cultural Heritage of Jamaica. Sevilla la Nueva - Archaeology." Jamaica National Heritage Trust. UNDP/UNESCO NATIONAL 
PROJECT JAM/86/oo1. Report on file at the Jamaic National Heritage Trust, Kingston, Jamaica.

López y Sebastián, Lorenzo E. 1986b. "El Proyecto Sevilla la Nueva, Jamaica. Primera Fase." Revista Espanola de Antropología Americana XVI: 295-302.

López y Sebastián, Lorenzo E. 1987. "Asentamientos Europes en America: El Caso de Sevilla la Nueva (Jamaica)." Report on file at the Jamaica National Heritage Trust, Kingston, Jamaica.

Morison, Samuel E. 1942. Admiral of the Ocean Sea: A Life of Christopher Columbus. Boston: Little, Brown, and Company.

Morison, Samuel E. 1963. Journals and Other Documents on the Life and Voyages of Christopher Columbus. New York: Heritage Press.

Osborne SJ, F.F. 1973. "The Spanish Church at Seville." Archaeology Jamaica 73: 3-11.

Padrón, Francisco M. 2003. Spanish Jamaica. Kingston: Ian Randle Publishers.

Patterson, Thomas C. 2010 "Archaeology Enters the 21st Century" in Handbook of Postcolonial Archaeology, edited by Jane Lydon and Uzma Z. Rizvi, 133-140. Walnut Creek: Left Coast Press.

Rouse, Irving. 1992. The Tainos: Rise and Decline of the People who Greeted Columbus. New Haven: Yale University Press.

Silliman, Stephen W. 2005. "Culture Contact or Colonialism? Challenges in the Archaeology of Native North America." American Antiquity 70 (1):55-75.

South, Stanley A. 1977. Method and Theory in Historical Archaeology. New York: Academic Press.

Valcárcel Rojas, Roberto, Alice V.M. Samson, and Menno L.P. Hoogland. 2013. "IndoHispanic Dynamics: From Contact to Colonial Interaction in the Greater Antilles." International Journal of Historical Archaeology 17 (1): 18-39.

Weddle, Robert S. 1985. Spanish Sea. The Gulf of Mexico in North American Discovery 1500-1685. College Station: Texas A\&M University Press.

Wesler, Kit W. 2013. "Jamaica." In The Oxford Handbook of Caribbean Archaeology, edited by William F. Keegan, Corinne L. Hofman, and Reniel Rodriguez Ramos, 250263. Oxford: Oxford University Press.

Wilson, Samuel M. 2007. The Archaeology of the Caribbean. Cambridge: Cambridge University Press.

Wing, Elizabeth S. 2001. "Native American Use of Animals in the Caribbean." In Biogeography of the West Indies: Patterns and Perspectives, edited by Charles A. Woods and Florence E. Sergile, 481-518. Boca Raton: CRC Press.

Wing, Elizabeth S. 2008. "Pets and Camp Followers in the West Indies." In Case Studies in Environmental Archaeology, edited by Elizabeth Reitz, C. Margaret Scarry, and Sylvia J. Scudde, 405-426. New York: Springer. 
Woodward, Robyn P. 1988. "The Charles Cotter Collection: A Study of the Ceramic and Faunal Remains from Sevilla la Nueva." Master thesis, Texas A\&M University.

Woodward, Robyn P. 2006a. "Medieval Legacies: The Industrial Archaeology of an Early Sixteenth-Century Sugar Mill at Sevilla La Nueva, Jamaica." PhD diss., Simon Fraser University.

Woodward, Robyn P. 2006b. "Taíno Ceramics from Post-Contact Jamaica." The Earliest Inhabitants: The Dynamics of the Jamaican Taíno Culture, edited by Lesley-Gail Atkinson, 161-176. Kingston: University of the West Indies Press.

Wright, Irene A. 1921. "The Early History of Jamaica (1511-1536)." English Historical Review 36 (141): 70-95.

Wynter, Sylvia. 1984. New Seville: Major Dates 1509-1536; New Seville: Major Facts, Major Questions. Kingston: National Historic Trust.

Yaeger, Timothy J. 1989. "Encomienda or Slavery? The Spanish Crown's Choice of Labor Organization in Sixteenth-Century Spanish America." Journal of Economic History 50: $842-859$. 